\title{
How Does Waiting Time Affect Anxiety and Pain in Adult Individuals Undergoing Venous Blood Drawing?
}

\author{
Venöz Kan Alma Uygulanan Yetişkin Bireylerde Bekleme \\ Süresi Kaygı ve Ağrıyı Nasıl Etkiler?
}

Özgün Araştırma Research Article

Received/Geliş: 28.11.2019 Accepted/Kabul: 11.05.2020

Published Online: 31.08 .2020

-

Dilek Orbatu Tepecik Eğitim ve Araştırma Hastanesi Çocuk Sağlığı ve Hastalıkları Kliniği, İmir - Türkiye drdilekorbatu@gmail.com ORCID: 0000-0002-5716-2938

B. Ulamış 0000-0002-0267-9470 S. Vermişli Peker 0000-0002-5306-6519 Tepecik Eğitim ve Araştırma Hastanesi Kan Alma Ünitesi, izmir, Türkiye

N. Yilmaz Özkalay 0000-0001-7435-2461 Tepecik Eğitim ve Araştırma Hastanesi Klinik Mikrobiyoloji, İmir, Türkiye

D. Alaygut 0000-0002-2164-4652 Tepecik Eğitim ve Araştırma Hastanesi Çocuk Sağlığı ve Hastalıkları Kliniği, İmir, Türkiye

Cite as: Ulamış B, Vermişli Peker S, Orbatu D, Yılmaz Özkalay N, Alaygut D. Venöz kan alma uygulanan yetişkin bireylerde bekleme süresi kaygı ve ağrııı nasıl etkiler?. Tepecik Eğit. ve kaygı ve ağriyı nasıl etkiler?. Tepecik E⿱⺌兀
Araşt. Hast. Dergisi. 2020;30(2):148-55.

\author{
Bilgen Ulamış $\oplus^{\oplus}$, Sevgi Vermişli Peker ${ }^{\oplus}$, Dilek Orbatu ${ }^{\oplus}$, Nisel Yılmaz Özkalay ${ }^{\oplus}$, \\ Demet Alaygut $\odot$
}

\section{ABSTRACT}

Objective: This study was conducted to determine the correlation between the waiting time and anxiety levels of the individuals in adult blood collection unit and the pain they felt during the procedure.

Method: This cross-sectional and descriptive study was conducted in Adult Blood Collection unit of a training, and research hospital between September and October 2018. The Case Report Form, Spielberg State-Trait Anxiety Inventory (STAI), and Visual Analog Scale (VAS) were used to collect the data. Descriptive statistics, Mann-Whitney U Test, Kruskal-Wallis Test, Post Hoc Dunn test with Bonferroni Correction, and Spearman Correlation Coefficient were used to assess the data.

Results: In this study including a total of 351 blood donors, the median age of the individuals was 43 (17-91)/years, $61 \%$ were female, and $63.8 \%$ had primary school and lower educational level. The median waiting time during the procedure was $6.0(0.0-62.0) / \mathrm{min}$. It was determined that $95.4 \%$ of the individuals had given blood before, $13.7 \%$ had hematoma on the venipuncture site, and $13.4 \%$ had needle phobia. The median VAS score of the individuals was 2.0 and $51.9 \%$ had mild pain. The median STAl score of the individuals was 59.0 (25.0-80.0). While a positive significant correlation was determined between the waiting time for giving blood and VAS score $(r=0.256, p<0.001)$, there was no significant correlation between the waiting time and STAI score ( $p>0.05)$. A negative significant correlation was determined between VAS and STAI scores $(r=-0.417, p<0.001)$.

Conclusion: Individuals feel mild pain and moderate anxiety during blood drawal. It was observed that as the waiting time of the individuals for giving blood increased, the pain they felt during the venipuncture increased but their anxiety levels were not affected.

Keywords: Blood sample, blood donor, waiting time, pain, anxiety

öz

Amaç: Bu araştırma, erişkin kan alma biriminde kan veren bireylerin bekleme süresi ile kaygı düzeyleri ve işlem sırasında hissedilen ağrı arasındaki ilişkiyi belirlemek amacıyla yapıldı.

Yöntem: Kesitsel ve tanımlayıcı tipteki araştırma, Eylül-Ekim 2018 tarihleri arasında bir eğitim araştırma hastanesinin Erişkin Kan Alma Biriminde yürütüldü. Verilerin toplanmasında olgu rapor formu, Spielberg Durumluluk Kaygı Ölçeği (DKÖ) ve Vizüel Anolog Skala (VAS) kullanıldı. Verilerin değerlendirilmesinde tanımlayıcı istatistikler, MannWhitney U Test, Kruskal- Wallis Test, Games-Howel Post Hoc Test ve Spearman Korelasyon katsayısı kullanıldı.

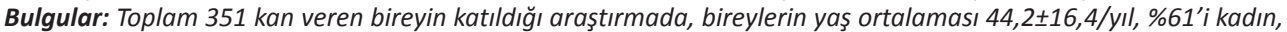
$\% 63,8$ 'i ilköğretim ve altı eğitim düzeyinde bulundu. Kan verme sırasında bekleme süresi ortalaması 11,7士13,6/dk. idi. Bireylerin \%95,4'ünün daha önce kan verdiği, \%13,7'sinin kan verdiği bölgede hematom oluștuğu, \%13,4'ünün iğne korkusu olduğu belirlendi. Bireylerin VAS puanı ortalaması 3,3 2,7 olup \%51,9'unun hafif ağrısı olduğu belirlendi. Bireylerin DKÖ puan ortalaması 58,5 $\pm 12,2$ idi. Kan vermek için beklenen süre ile VAS puanı arasında pozitif yönde anlamlı ilişki $(r=0,256, p=0,000)$ saptanırken beklenen süre ile DKÖ puanı arasında anlamlı ilişki yoktu $(p>0,05)$. VAS puanı ile DKÖ puanı arasında ise negatif yönde anlamlı ilişki saptandı $(r=-0,417, p=0,000)$.

Sonuç: Bireyler, kan verme sırasında hafif düzeyde ağrı ve orta düzeyde kaygı hissetmektedir. Bireylerin kan vermek için bekleme süresi arttıkça kan alma sırasında hissedilen ağrının da arttığı ancak kaygı düzeylerinin etkilenmediği görüldü.

Anahtar kelimeler: Kan örneği, kan veren birey, bekleme süresi, ağrı, anksiyete

(C) Telif hakkı TC. Sağlık Bakanlı̆ı i̇zmir Tepecik Eğit. ve Arast. Hastanesi. Logos Tip Yayıncluk tarafindan yayınlanmaktadır.

Bu dergide yayınlanan bütün makaleler Creative Commons Atf-GayriTicari 4.0 Uluslararası Lisansı ile lisanslanmıştr.

(c) Copyright Association of Publication of the T.C. Ministry of Health Izmir Tepecik Education and Research Hospital.

This journal published by Logos Medical Publishing.

Licenced by Creative Commons Attribution-NonCommercial 4.0 International (CC BY) 


\section{INTRODUCTION}

Venipuncture procedure is an important trauma that should not be ignored for all blood donors including children or adults ${ }^{(1)}$. After venipuncture, acute pain is one of common patient complaints along with local complications such as ecchymosis and hematoma and physiological complications such as tachycardia and hypotension ${ }^{(2)}$. Decreasing the pain and anxiety is an important part of the care given by healthcare professionals ${ }^{(3,4)}$. There are many factors that cause pain and anxiety in people in a hospital environment. One of them is waiting times in hospitals. Despite organizational advances in health services, patients still face unwanted waiting times in today's hospitals. They wait mainly for the doctor, and then for the examinations, and tests or wait in line due to an accident or an emergency situation or to present their examination results. It is known that waiting time in hospitals affects the service procurement and service quality received by the patients ${ }^{(5)}$. It is also known that waiting time brings some emotional factors that may affect the quality of life of the patients. For example, a study conducted with the patients in the waiting list for hepatic tests, and procedures revealed that these patients needed additional auxiliary factors to reduce their anxiety and stress ${ }^{(6)}$. Being sick, staying in hospital, having an examination and surgical intervention affect the lives of individuals in many aspects (7). Patients' anxiety levels may be affected by various factors such as their previous experiences, ways of coming to the hospital, gender, age, examinations, and surgical procedures they will have ${ }^{(8)}$. When we add the waiting time among these factors, the result can be more dramatic.

In general meaning, anxiety is the emotional response of the human beings to existing, environmental and psychological events ${ }^{\left({ }^{9}\right)}$. Waiting for an unknown and incoherent danger causes unrest and tension in a person. While "trait anxiety" is defined as the anxiety type making the individuals feel that their self- values are threatened and leading them to perceive the situation as stressful, "state anxiety" is defined as the stationary anxiety type seen due to the temporary situation caused by dangerous conditions ${ }^{(10)}$. This study was conducted to determine the correlation between the waiting time and anxiety levels of the individuals in adult blood collection unit and the pain they felt during the procedure.

\section{MATERIAL and METHOD}

This cross-sectional and analytical study was conducted between September 2018 and October 2018 in adult blood collection and sample collection unit providing service in Izmir Tepecik Training and Research Hospital of T.R. Ministry of Health Science of University Tepecik Training and Research Hospital. Nearly 700-900 patients apply to the blood center where the research is conducted and 10 blood collection nurses are working. The universe of the study was composed of individuals who applied to the blood collection unit within a month and agreed to participate in the study. The study was carried out by a nurse selected by the researchers because of her professional experience and competence. The waiting time of the patients was determined using analytical-based artificial intelligence information management system used in blood collection unit of the hospital. Individuals having diseases affecting pain threshold such as diabetes mellitus (DM), polyneuropathy, a psychiatric disorder, those using antidiabetic and antidepressant drugs, and aged $<18$ years, illiterates, and individuals who refused to participate were excluded from the study.

\section{Data Collection Method}

The Case Report Form (CRF) prepared upon the literature review, Visual Analog Scale (VAS) in the range of 1-10, and Spielberg State-Trait Anxiety Inventory (STAI) were used to collect the data.

\section{Data Collection Tools}

The Case Report Form (CRF): CRF, developed by rese- 
archers upon the literature review, consists of two parts ${ }^{(2)}$. The first part includes eight questions about sociodemographic characteristics (age, gender, marital status, educational status, income status etc.) and the second part includes five questions about venipuncture experiences (hemophobia, previous bloodgiving experience, previous negative experiences, etc.).

Spielberg State-Trait Anxiety Inventory (STAI): StateTrait Anxiety Inventory is composed of a total of 20 items. There is no time limit for answering the scale. Response options, which are formulated on a 4-point Likert type of the scale as follows: 1 not at all," 2 "somewhat," 3 "moderately so," and 4 for "very much There are two types of expressions in the State-Trait Anxiety Scale: direct and reversed. Direct expressions are related to 3., 4., 6., 7., 9., 12., 13., 14., 17. and 18. Items. The reverse statements are related to $10,1 ., 2$, 5., 8., 10., 11., 15., 16., 19. and 20. items. In the evaluation, the total score of the expressions was calculated first, and then the total score of the 10 reverse expressions, and the total score of the inverted expressions was subtracted from the total score of the direct expressions. By adding 50 points, which is a constant value for the State Anxiety-Trait Scale, the score obtained by the individual from the State Anxiety-Trait Scale was determined. The total score obtained from the scale can range from 20 to 80 . A high score indicates that the level of anxiety is high, and a small score indicates that the level of anxiety is low. State-Anxiety Inventory was developed by Spielberg et al., in 1970 and adapted into Turkish by Öner and Le Compte in 1977. Emotion or behaviors expressed in the items of State-Trait Anxiety Inventory are responded by marking one of the options such as (1) never (2) a little (3) a lot (4) completely according to the severity of such experiences. There are two types of expressions in the scale. We can call them direct or reverse statements. While direct statements express negative emotions, reversed statements express positive emotions. Answers receiving 4 points in the direct statements indicate high anxiety. In the reversed statements, answers receiving 1 point refer to high anxiety and those receiving 4 points refer to low anxiety ${ }^{(11)}$.

Visual Analog Scale (VAS): Developed by Price et al. (10). It is used to evaluate the severity of pain on a $10-\mathrm{cm}$ long scale and applied by marking a point on the vertical or horizontal line that corresponds to the severity of pain felt by the patient as $0=$ no pain, $10=$ worst pain)

\section{Data Analysis}

SPSS 22.0 software package was used to evaluate the data in the study. Whether the data showed normal distribution or not was determined by ShapiroWilks test. Descriptive statistics, Mann-Whitney U Test, Kruskal-Wallis Test, Post-Hoc Dunn Test with Bonferroni Correction, and Spearman Correlation Test were used to assess the data. The level of significance accepted for the results was $p<0.05$.

\section{Ethical Considerations}

The study was conducted in accordance with the Declaration of Helsinki. Prior to the study, written permission from the center where the study was conducted, scientific ethics committee approval from the local ethics committee of the research center (2018/10-2, 08/08/2018) and written and verbal consents from the patients participating in the study via informed consent forms were obtained.

\section{Limitations of the Study}

Since the study was conducted with patients in the adult blood collection and sampling units of Tepecik Training and Research Hospital of T.R. Ministry of Health University of Health Sciences, its results cannot be generalized to all adult blood donors.

\section{RESULTS}

Sociodemographic characteristics of a total of 351 study patients are shown in Table 1 . The study popu- 
lation consisted of 214 (61\%) female, and 137 (39\%) male participants. Income levels of 172 (49.0\%) patients were less than their expenses, $68.7 \%(n=241)$ were married, $63.8 \%(n=224)$ had primary school or lover educational level, $51 \%(n=179)$ were living in

Table 1. Sociodemographic characteristics of the participants.

\begin{tabular}{|c|c|c|c|}
\hline Variables & & $N=(351)$ & $\%$ \\
\hline \multirow[t]{2}{*}{ Gender } & Male & 137 & 39.0 \\
\hline & Female & 214 & 61.0 \\
\hline \multirow[t]{3}{*}{ Income Status } & Income less than expenses & 172 & 49.0 \\
\hline & Income equal to expenses & 163 & 46.4 \\
\hline & Income more than expenses & 16 & 4.6 \\
\hline \multirow[t]{2}{*}{ Marital Status } & Married & 241 & 68.7 \\
\hline & Single & 110 & 31.3 \\
\hline \multirow[t]{3}{*}{ Educational Status } & Primary school and lower & 224 & 63.8 \\
\hline & Highs school and associate degree & 89 & 25.4 \\
\hline & Bachelor's degree and higher & 38 & 10.8 \\
\hline \multirow[t]{3}{*}{ Place of residence } & City center of Izmir & 148 & 42.2 \\
\hline & Districts of Izmir & 179 & 51.0 \\
\hline & Outside of Izmir & 24 & 6.8 \\
\hline \multirow[t]{3}{*}{ Profession } & Unemployed & 163 & 46.4 \\
\hline & Public or private sector employees & 103 & 29.3 \\
\hline & Retired & 85 & 24.2 \\
\hline \multirow[t]{2}{*}{ Age Group } & Under 65 years & 304 & 86.6 \\
\hline & 65 years old and older & 47 & 13.4 \\
\hline \multirow[t]{2}{*}{ Smoking } & Yes & 92 & 26.2 \\
\hline & No & 259 & 73.8 \\
\hline \multirow[t]{3}{*}{ Alcohol } & Yes & 30 & 8.5 \\
\hline & No & 321 & 91.5 \\
\hline & & \multicolumn{2}{|c|}{ Med (Min-Max) } \\
\hline \multicolumn{2}{|l|}{ Age/year } & \multicolumn{2}{|c|}{$43.0(17-91)$} \\
\hline
\end{tabular}

Med: Median, Min: Minimum, Max: Maximum

Table 2. Information about the blood giving experiences of the participants.

\begin{tabular}{llcc}
\hline Variables & & N=(351) & $\%$ \\
\hline Blood giving experience & More than one & 335 & 95.4 \\
& First time & 16 & 4.6 \\
Passing out during & Yes & 13 & 3.7 \\
venipuncture before & No & 338 & 96.3 \\
Vomiting during & Yes & 2 & 0.6 \\
venipuncture before & No & 249 & 99.4 \\
Edema in the venipuncture & Yes & 21 & 6.0 \\
area before & No & 330 & 94.0 \\
Hematoma in the & Yes & 48 & 13.7 \\
venipuncture area before & No & 303 & 86.3 \\
Inability to find a vein in & Yes & 51 & 14.5 \\
one trial before & No & 300 & 85.5 \\
The reason for fear in & No fear & 265 & 75.5 \\
blood drawn & Needle Fear & 47 & 13.4 \\
& Seeing blood/hemophobia & 15 & 4.3 \\
& Pain Anxiety & 8 & 2.3 \\
& Risk of Infection & 3 & 0.9 \\
Coming to give blood with & Year of medical procedures & 13 & 3.7 \\
a relative & No & 170 & 48.4 \\
Waiting time/minute during venipuncture & 181 & 51.6 \\
& & Med (Min-Max)
\end{tabular}

Med: Median, Min: Minimum, Max: Maximum the districts of Izmir province, $46.4 \%(n=163)$ were unemployed, $26.2 \%(n=92)$ were smoker, and $8.5 \%$ $(n=30)$ were using alcohol. The median age of the participants was determined as 43 (min:17-max:91) years and $86.6 \%$ were below 65 years of age. Table 2 shows information about the blood giving experiences of the individuals. It was determined that $95.4 \%$ $(n=335)$ of the participants had given blood before, $3.7 \%(n=13)$ passed out during venipuncture, $0.6 \%$ $(n=2)$ vomited, $6.0 \%(n=21)$ had edema, and $13.7 \%$ $(n=48)$ had hematoma on the venipuncture site, and veins of $14.5 \%(n=51)$ of the patients could not be found in one trial. It was determined that $48.4 \%$ $(n=170)$ of the participants came to the blood collection unit with a relative, $75.0 \%(n=265)$ were not afraid of giving blood, $13.4 \%(n=44)$ had needle phobia, $4.3 \%(n=15)$ had fear of seeing blood/hemophobia, and $2.3 \%(n=8)$ had algophobia The median waiting time of the individuals during venipuncture procedure was 6.0 (min:0-max:62) minutes. Table 3 displays the VAS and State-Trait Anxiety Inventory (STAI) scores of the individuals participating in the study. It was determined that the median VAS score of the participants was 2.0 (min:0.0-max:9.5) and when their VAS scores were grouped, $51.9 \%(n=182)$ had mild pain; whereas, $16.5 \%(n=58)$ had severe pain. The median State-Trait Anxiety Inventory score

Table 3. VAS and state anxiety inventory scores of the participants.

\begin{tabular}{llcc}
\hline Variables & & $\mathbf{N}=(\mathbf{3 5 1})$ & $\%$ \\
\hline \multirow{3}{*}{ VAS GROUP } & Mild Pain & 182 & 51.9 \\
& Moderate Pain & 111 & 31.6 \\
& Severe Pain & 58 & 16.5 \\
VAS Score & & Med (Min-Max) \\
State Anxiety Score & $2.0(0.0-9.5)$ \\
& & $59.0(25.0-80.0)$
\end{tabular}

Med: Median, Min: Minimum, Max: Maximum

Table 4. Correlation between the waiting time, VAS, and state anxiety inventory scores of the participants.

\begin{tabular}{lcccccc}
\hline \multirow{2}{*}{ Variables } & \multicolumn{2}{c}{ VAS Score } & & \multicolumn{2}{c}{ State Score } \\
\cline { 2 - 3 } \cline { 5 - 6 } & $\mathbf{r}$ & $\mathbf{p}$ & & $\mathbf{r}$ & $\mathbf{p}$ \\
\hline State Anxiety Score & -0.417 & $<0.001^{* *}$ & & \\
Waiting Time & 0.259 & $<0.001^{* *}$ & & 0.031 & 0.533 \\
\hline
\end{tabular}

${ }^{* *} p<0.001$, Spearman Correlation 
Table 5. Distribution of Sociodemographic Characteristics and VAS and State Anxiety Scores of the Participants.

\begin{tabular}{|c|c|c|c|c|c|c|c|c|c|}
\hline \multirow[b]{2}{*}{ Variables } & & \multirow{2}{*}{$\frac{\text { VAS Score }}{\operatorname{Med}(\min -\max )}$} & \multicolumn{2}{|c|}{ Test Statistics } & \multirow{2}{*}{ Post-hoc } & \multirow{2}{*}{$\begin{array}{l}\begin{array}{c}\text { State Anxiety } \\
\text { Score }\end{array} \\
\text { Med (min-max) }\end{array}$} & \multicolumn{2}{|c|}{ Test Statistics } & \multirow[b]{2}{*}{ Post-hoc } \\
\hline & & & $z / X^{2}$ & $\bar{p}$ & & & $z / X^{2}$ & $\mathbf{p}$ & \\
\hline \multirow[t]{4}{*}{ Gender } & Male $(n=137)$ & $2.0(0.0-9.0)$ & -2.377 & 0.017 & $\mathrm{M}<\mathrm{F}$ & $61.0(28.0-80.0)$ & -2.256 & 0.024 & $M>F$ \\
\hline & Female $(n=214)$ & $2.0(0.0-9.5)$ & & & & $58.0(25.0-80.0)$ & & & \\
\hline & Primary school and lower (A) & $2.0(0.0-9.5)$ & 0.482 & 0.786 & $A=B=C$ & $57.0(27.0-80.0)$ & 19.203 & $<0.001$ & $A<B$ \\
\hline & High school and associate degree (B) & $1.5(0.0-9.2)$ & & & & $64.0(25.0-80.0)$ & & & $A<C$ \\
\hline Educational Status & Bachelor's degree and higher (C) & $2.0(0.0-9.0)$ & & & & $60.5(38.0-80.0)$ & & & $B=C$ \\
\hline \multirow[t]{2}{*}{ Coming with a relative } & Yes $(n=13)$ & $2.5(0.0-9.5)$ & -1.659 & 0.097 & $Y=N$ & $58.0(25.0-80.0)$ & -2.237 & 0.025 & $\mathrm{Y}<\mathrm{N}$ \\
\hline & No $(n=338)$ & $2.0(0.0-9.20)$ & & & & $60.0(27.0-80.0)$ & & & \\
\hline \multirow{2}{*}{$\begin{array}{l}\text { Passing out during venipuncture } \\
\text { before }\end{array}$} & Yes $(n=170)$ & $6.0(2.0-9.0)$ & -2.118 & 0.034 & $\mathrm{Y}>\mathrm{N}$ & $48.0(25.0-59.0)$ & -3.722 & $<0.001$ & $\mathrm{Y}<\mathrm{N}$ \\
\hline & No $(n=181)$ & $2.0(0.0-9.5)$ & & & & $59.0(27.0-80.0)$ & & & \\
\hline
\end{tabular}

Med:Median, Min: Minimum, Max: Maximum, z: Mann Whitney U Test, $X^{2}$ : Kruskal Wallis Test, Dunn's Post Hoc Test (significance values have been adjusted by the Bonferroni correction for multiple tests)

of the participants was 59.0 (min:25.0-max:80.0).

Table 4 shows the correlation between waiting time, VAS and state-trait anxiety inventory scores of the participants. No statistically significant correlation was found between the waiting time for giving blood and the state anxiety inventory scores. A positive correlation was determined between the waiting time for giving blood and VAS scores $(r=0.256$, $p<0.001)$. A negative correlation was found between the VAS and the state anxiety scores of the blood donors $(r=-0.417, p<0.001)$. VAS and state anxiety scores of the blood donors were investigated in terms of their sociodemographic characteristics and blood giving experiences. Table 5 shows the information about the cases causing a statistically significant difference. Median VAS score of the men was 2.0 (0.0-9.0) which was statistically significantly lower than that of the women $(z=-2.377, p=0.017)$. Median VAS score was 6.0 (2.0-9.0) in those who had passed out during venipuncture procedure before which was statistically significant higher compared to those who never passed out $(z=-2.118, p=0.034)$. The median state-trait anxiety inventory (STAI) score of the men was 61.0 (28.0-80.0) which was statistically significantly higher than that of women $(z=-2.256$, $\mathrm{p}=0.024)$. The median STAl score was 57.0 (27.080.0 ) in those having primary school or lower educational level and was statistically significantly lower than the others $\left(X^{2}=19.2013, p<0.001\right)$. The median STAI score of those who came with a relative was 58.0 (25.0-80.0) which was statistically significantly lower $(z=-2.237, p=0.025)$. The median STAI score was 48.0 (25.0-59.0) for those who passed out during venipuncture procedure before and it was statistically significantly lower than those who never passed out before $(z=-3.722, p<0.001)$.

\section{DISCUSSION}

This study was conducted with adults in a blood collection unit of a tertiary hospital and the impact of waiting time on pain and anxiety was evaluated. When the literature is evaluated, studies related to the pain and anxiety experienced by patients in different areas of the health centers are encountered, but limited number of studies have been performed on the patients in the blood collection unit. However, when the national and international literatures are reviewed, any study investigating the relationship between the waiting time before the procedure in adult blood donors and their anxiety and pain levels during the procedure has not been reported yet. In addition, according to our knowledge, the unfavourable impact of the pain and anxiety related to the longer waiting periods has not been investigated before. However, it is possible to come across publications related to the waiting period during the preoperative period. In a study conducted to examine the effect of waiting time in premedication room on anxiety levels of patients scheduled for elective surgery, it was stated that the waiting time caused anxiety and it is important to ensure that patients had a 
relative with them until they were taken to the operation room and provide an environment where they can listen music or watch television in order to reduce their anxiety and distress ${ }^{(12)}$. In the literature, there are studies conducted to evaluate the waiting time and anxiety levels of the patients during the procedure in diagnostic or therapeutic interventions associated with pain ${ }^{(13-15)}$.

With the participation of 351 patients (61\% women), the correlation between waiting time and anxiety and pain levels of the patients in adult blood collection unit was evaluated in the present study. The results of the present study were evaluated together with studies investigating the effects of waiting time on anxiety and pain before other interventional procedures. When examining the studies evaluating the effects of waiting time before diagnostic and therapeutic procedures performed on patients and healthy individuals, pain and anxiety have been among the important emphasized parameters ${ }^{(15,16)}$. Although the thought that the waiting time may increase the levels of anxiety and pain of the patients, there was no significant relationship between the waiting time for blood donation and the state-trait anxiety inventory in this study. If increase in the levels of anxiety is expected, and the reason why the relationship between waiting time and anxiety could not be detected is explored, a few factors may attract attention. The main reason for the anxiety of the patient that occurs in the preprocedural period is the fear of the unknown ${ }^{(16)}$. Anxiety or pain associated with medical interventions has been associated with a wide variety of factors, such as the patient's not being informed about the examination, and the previous knowledge of the diagnosis or course of the disease ${ }^{(18)}$. Unfamiliar hospital environment, loss of control, lack of information are factors that cause anxiety in the hospital environment. The waiting room in the blood collection center is such that waiting patients can sit and observe the patients to be sampled before and after the procedure. Being informed by observing the procedure to be performed and sharing with other patients waiting for the same procedure may decrease anxiety levels caused by the prolonged waiting time. For stronger interpretations, such studies need to be repeated in larger populations. However, studies on this subject are not encountered in the literature. Anxiety is commonly seen in a great majority of individuals who apply to a health institution and it is known to be a factor increasing pain related to interventional procedures (16). Pain and anxiety may cause vagal nerve stimulation and may lead to a decrease in vasodilation and perfusion. It is stated that anxiety seen before interventional procedures maximizes during the procedure and increases the severity of pain felt by the patient.

In this study, the severity of pain felt during venipuncture was evaluated with visual analog scale (VAS) and it was found to be lower in men than women and higher in those who passed out during previous venipunctures than those who did not. There is a lot of evidence to show that gender is an important factor in modulating pain. Literature data strongly suggest that men and women differ in their responses to pain.Indeed, women are more variable in their feelings of pain than men and have increased pain sensitivity Gender differences in pain arise from the interaction of genetic, anatomical, physiological, neuronal, hormonal, psychological and social factors that modulate different pain levels in both genders. Experimental data indicate that both a different modulation of the endogenous opioid system and sex hormones are factors influencing pain sensitivity in males and females ${ }^{(19)}$. Androgens and estrogens are essential for the development and maintenance of the reproductive system and many studies suggest that they also play an important role in the observed differences between males and females in the response to pain and pain treatments. Changes in estrogen plasma levels were found to be correlated with recurrent pain in women ${ }^{(20)}$. In our study, higher VAS scores of women can be explained by this phenomenon. When its correlation with the was 
examined, VAS score showed a positive correlation with the waiting time ${ }^{(21)}$. In the literature, waiting time before diagnostic and therapeutic procedures is indicated to be among the main causes of anxiety felt by individuals from health institutions and during procedures ${ }^{(14,15)}$. Pontone et al. ${ }^{(15)}$ determined that patients with high anxiety level before endoscopy felt higher level of pain during the procedure. In their study, Sidar et al. ${ }^{(22)}$ found a statistically significant correlation between the pain level and state anxiety level in patients hospitalized in the intensive care unit of cardiovascular surgery after open heart surgery; on the other hand, no significant correlation was found between the waiting time for giving blood and anxiety levels of the individuals. Similarly, in our study, there was no significant difference between waiting time and anxiety levels. Reducing the anxiety levels of individuals before venipuncture process can reduce the pain they felt during venipuncture which can also contribute to the increase of patient satisfaction, which is one of the quality indicators of delivery of health care. Developing patient training programs and materials specific to individuals and procedures and to organize planned patient trainings are recommended ${ }^{(4,7)}$. We believe that all healthcare professionals working in the blood collection unit should be trained to inform the blood donors so as to eliminate their anxieties and fears. When the average waiting time of the individuals for venipuncture procedure and patient circulation of the unit are considered, a joint video display to inform the patients before the procedure may be recommended.

Ethics Committee Approval: The approval of Health Sciences University İzmir Tepecik Health Application Research Center Non-Invasive Ethics Committee was obtained (2018/10-2).

Conflict of Interest: None.

Funding: None.

Informed Consent: None.

\section{REFERENCES}

1. Ince $S$, Khorshid L. Kan bağışı nedeniyle gelişen komplikasyonlar. Turkiye Klinikleri Journal of Nursing Sciences. 2016;8(1):53-61. [CrossRef]

2. Birgili Y, Aydın Ş. Kan veren bireylerde kan alma sırasında görülen olumsuz belirti-bulguların ve kaygı düzeylerinin incelenmesi. Hacettepe Üniversitesi Hemşirelik Fakültesi Dergisi 2011;18(2):17-26.

3. Meiri N, Ankri A, Hamad-Saied M, Konopnicki M, Pillar G. The effect of medical clowning on reducing pain, crying, and anxiety in children aged 2-10 years old undergoing venous blood drawing a randomized controlled study. European Journal of Pediatrics. 2016;175(3):373-9. [CrossRef]

4. Vermişli S, Çukurova I, Baydur H, Yılmaz E. Relationship between preoperative patient learning need and anxiety of patients hospitalized at Ear Nose Throat and Head Neck Surgery clinic for surgical treatment. The Turkish Journal of Ear Nose and Throat. 2016;26(2):79-91. [CrossRef]

5. Thompson DA, Yarnold PR, Williams DR, et al. Effects of actual waiting time, perceived waiting time, information delivery, and expressive quality on patient satisfaction in the emergency department. Ann Emerg Med. 1996;28(6):657-65. [CrossRef]

6. Teixeira HR, Marques DM, Lopes AR, Ziviani LC, Magro JT, Mente ÊD, Castro-E-Silva O, Galvão CM, Mendes KD. Anxiety and Stress Levels on Liver Transplantation Candidates. Transplant Proc. 2016;48(7):2333-7. [CrossRef]

7. Taşdemir A, Erakgün A, Deniz MN, Çertuğ A. Preoperatif bilgilendirme yapılan hastalarda ameliyat öncesi ve sonrası kaygı düzeylerinin State-Trait Anxiety Inventory test ile karşılaştırılması. Turk J Anaesth Reanim. 2013;41:44-9.

8. Dolgun E, Candan Dönmez Y. Hastaların ameliyat öncesi döneme ait bilgi gereksinimlerinin belirlenmesi. Maltepe Üniversitesi Hemşirelik Bilim ve Sanatı Dergisi. 2010;3:10-5.

9. Barlow D. H. Unraveling the mysteries of anxiety and its disorders from the perspective of emotion theory. American Psychologist. 2000;55(11):1247. [CrossRef]

10. Weeks P, Hayley A, Stough C. Do individual differences in state and trait anxiety predict sleep difficulties in healthy older adults? Personality and Individual Differences. 2019;144:141-6. [CrossRef]

11. Durmuş S, Günay O. Hemşirelerde iş doyumu ve anksiyete düzeyini etkileyen faktörler. Erciyes Tıp Dergisi. 2007;29(2): 139-46.

12. Deliktaş HK, Açıkgöz T, Çelik S. Elektif Operasyon Planlanan Hastaların Premedikasyon Odasında Bekleme Sürelerinin Anksiyete Seviyelerine Etkisi. The Medical Bulletin of Sisli Etfal Hospital. 2017;51:4.

13. Carta G, Palermo P, Marinangeli F, Piroli, A, Necozione S, De Lellis V, Patacchiola F. Waiting time and pain during office hysteroscopy. Journal of minimally Invasive Gynecology. 2012;19(3):360-4. [CrossRef]

14. Azmi N, Chan WK, Goh KL. Evaluation of patient satisfaction of an outpatient gastroscopy service in an Asian Tertiary Care Hospital. BMC Gastroenterol. 2012;12:96. [CrossRef]

15. Pontone S. Tonda M, Brighi M, Florio M, Pironi D, Pontone P. Does anxiety or waiting time influence patients' tolerance of upper endoscopy ? Saudi journal of gastroenterology: official journal of the Saudi Gastroenterology Association. 2015;21(2):111. [CrossRef]

16. Saraçoğlu T, Unsal A, Taşkın F, Sevinçok L, Karaman CZ. The impact of pre-procedural waiting period and anxiety level on 
pain perception in patients undergoing transrectal ultrasound-guided prostate biopsy. Diagn Interv Radiol. 2012;18(2):195-9. [CrossRef]

17. Vaughn F, Wichowski H, Bosworth G. Does Preoperative Anxiety Level Predict Postoperative Pain? AORN J. 2007;85(3):589-604. [CrossRef]

18. Andrewes D, Camp K, Kilpatrick C, Cook M. The assessment and treatment of concerns and anxiety in patients undergoing presurgical monitoring for epilepsy. Epilepsia. 1999;40(11):1535-42. [CrossRef]

19. Pieretti S, Di Giannuario A, Di Giovannandrea R, Marzoli F,
Piccaro G, Minosi P, Aloisi AM. Gender differences in pain and its relief. Ann Ist Super Sanita. 2016;52(2):184-9.

20. Marcus DA. Interrelationships of neurochemicals, estrogen, and recurring headache. Pain. 1995;62:129-39. [CrossRef]

21. Zisman A, Leibovici DAN, Kleinmann J Siegel YI, Lindner A. The impact of prostate biopsy on patient well-being:a prospective study of pain, anxiety and erectile dysfunction. The Journal of Urology. 2001;165(2):445-54. [CrossRef]

22. Sidar A, Dedeli Ö, İşkesen Aí. Açık Kalp Cerrahisi Öncesi ve Sonrası Hastaların Kaygı ve Ağrı Distresi: Ağrı Düzeyi ile İlişkisinin İncelenmesi. Yoğun Bakım Dergisi. 2013;4:1-8. 